\title{
低エネルギー $\boldsymbol{\gamma}$ 線による浮遊土砂量の測定
}

\author{
蒔田 実, 阿部辰数 \\ 建設省土木研究所 \\ 1966年 8 月30日 受理
}

\section{1. はじめに}

流水中の浮遊土砂量え知ることは, 土木工学上きわ めて重要なことである。従来, 浮遊土砂量は採水した 試料を师乾燥し秤量して求めているが, 迅速で精確 な，しかも簡便な方法としては満足できるものでな く，その測定法の開発が強く望まれている。

従来の測定法に対し， $\gamma$ 線の透過汇よる測定法は迅 速で簡便な方法として大いに期待される。しかし, 流 水中の浮遊土砂はわずかで, しかも, 土砂と水の $\gamma$ 線 に対する吸収係数の差が小さいなどの制約があり, 測 定精度の点で, $\gamma$ 線の透過による測定にはかなりの困 難が予想される1)。そこで, $\gamma$ 線透過による浮遊土砂 量の測定が, 実質的に可能かどうかを, 低エネルギー $\gamma$ 線 $\left({ }^{241} \mathrm{Am}\right.$ の $\left.60 \mathrm{keV}\right)$ を利用し, 室内実験により検討 を加えた。

\section{2. 実験装置・方法}

実験装置の概略をFig. 1 に示す。中央の容器はプラ

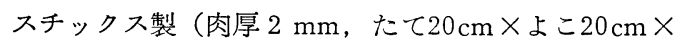

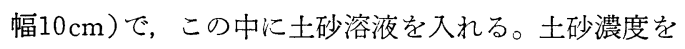
できるだけ均一にするため, 測定中もたえずミキサー で䚓拌する。 $\gamma$ 線源に ${ }^{241} \mathrm{Am}, 100 \mathrm{mCi}$ を用いた。検 出器にはシンチレーションカウンター $(\mathrm{NaI}(\mathrm{Tl}) 0.5$ in. $\phi \times 1$ in.）を波高分析器と組み合わせ用いた。

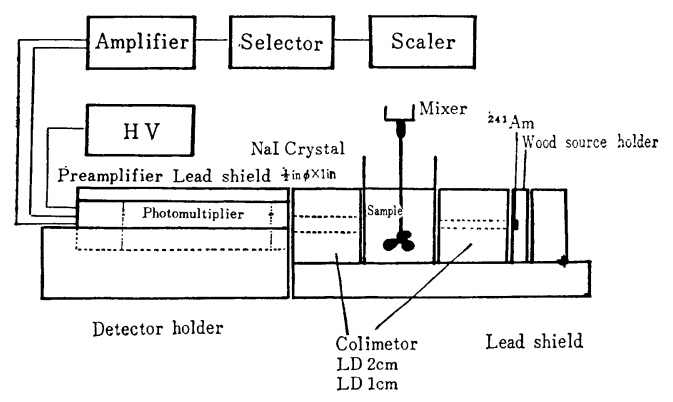

Fig. 1 Arrangement of experimental apparatus. $\gamma$ 線は $x \mathrm{~cm}$ の水中を透過するとき，その強度は指 数関数的に減少し, 透過前後の強度 $I_{0}, I_{1}$ の間に次式 の関係が成り立つ。

$$
I_{1}=I_{0} \exp \left[-\mu_{1} \rho_{1} x\right]
$$

ここで, $\mu_{1}$ : 水の質量吸収係数

$$
\rho_{1} \text { : 水の比重 }
$$

いま，水中に $P \mathrm{mg} / l$ の土砂が含まれたとすると，そ のときの $\gamma$ 線強度 $I_{2}$ は(2)式で示される。

$$
\begin{aligned}
I_{2}= & I_{0} \exp \left[-\mu_{1} \rho_{1} x\left(1-\frac{P \times 10^{-6}}{\rho_{2}}\right)\right. \\
& \left.-\mu_{2} \cdot\left(P \times 10^{-6}\right) x\right] \quad(2) \\
\therefore \quad \frac{I_{2}}{I_{1}} & =\operatorname{epx}\left[-\left(P \times 10^{-6}\right) \cdot\left(\frac{\mu_{2} \rho_{2}-\mu_{1} \rho_{1}}{\rho_{2}}\right) x\right]
\end{aligned}
$$

ただし， $\mu_{2}$ ：土砂の質量吸収係数

$$
\rho_{2}: \text { 土砂の比重 }
$$

$\gamma$ 線の透過前後の強度 $I_{0}, I_{2}$ から(2)式により, その ときの含有土砂量を測定することができるが，本実験 では $I_{0}$ に比し $I_{2}$ はきわめて小さく， $I_{2}$ を $I_{0}$ と対比さ せることは実際的でない。そこで，I0のかわりに土砂 を含有しないときの透過後の $\gamma$ 線強度 $I_{1}$ を基準にし, (3)式を用い，含有士砂量の測定法を検討することにし た。

土砂の試料として, 多摩ローム, 武蔵ローム, 黒ボ ク, 鹿沼土, ベントナイトおよび長野県美和ダムに堆 積した土, 計 6 種を用い, それぞれ 1000〜40000 ppm まで 4 〜 通りの濃度の土砂溶液を作成した。それぞ れの土砂試料につき，(3)式の関係を実測した。

\section{3. 結果および考察}

$\gamma$ 線の透過後の計数比 $\left(I_{2} / I_{1}\right)$ と土砂濃度 $(P)$ との 関係の実測結果をFig. 2 に示す。 6 種類の土とも, 当 然のことながら計数比と土砂濃度とは半対数グラフ上 きわめて良い直線関係を示し，乙かも，かなりの勾配 があり， $\gamma$ 線透過法による含有土砂量測定が十分可能 


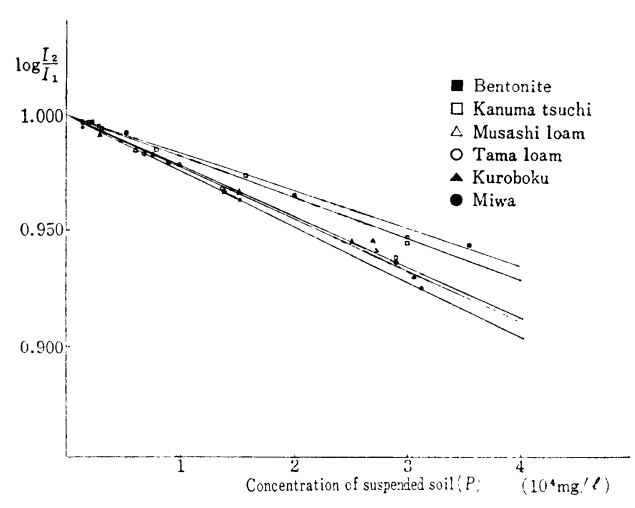

Fig. 2 Absorption curves of $60 \mathrm{keV} \gamma$-rays by the suspended soils.

であることを示している。

検出器による計測值はもちらん統計的変動をし, こ の変動は当然測定誤差を生ずる。測定精度を $1 \sigma$ とす れば，本実験のように計数率 $2 \times 10^{5} \mathrm{cpm}$, 訫測時間 10 minでは, その統計的変動による誤差は計数比にし て約 0.001 となる。これは Fig. 2 の直線の勾配から換 算すると，土砂濃度にして $500 \mathrm{mg} / l$ に相当する。

また, Fig. 2 は計数比と含有土砂濃度との関係が土 の種類によって異なることを示している。Fig. 2 の直 線の勾配から, ${ }^{241} \mathrm{Am}$ の $60 \mathrm{keV} \gamma$ 線に対する各種土 の吸収係数を求め Table 1 の結果を得た。各種土の化

Table 1 Absorption coefficient of the soils

\begin{tabular}{l|c|c|c}
\hline \multirow{2}{*}{ Types of soil } & Sp. gravity & \multicolumn{2}{|c}{ Absorption coefficient } \\
\cline { 2 - 4 } & & $\left(\mathrm{cm}^{2} / \mathrm{g}\right)$ & $\left(\mathrm{cm}^{-1}\right)$ \\
\hline Miwa & 2.70 & 0.332 & 0.896 \\
Tama loam & 2.72 & 0.306 & 0.832 \\
Musashi loam & 2.67 & 0.306 & 0.817 \\
Kuroboku & 2.48 & 0.322 & 0.799 \\
Kanumatsuchi & 2.49 & 0.270 & 0.672 \\
Bentonite & 2.63 & 0.249 & 0.655 \\
\hline
\end{tabular}

学組成は Table 2 のと㧍りで, 化学組成から算出した 吸収係数はほぼ実測結果と一致していることを示して いる。なお，Ig. loss は主として有機物であらうが, この場合すべて水分と仮定して算出した。土砂の吸収 係数に影響を与克るのは, 主として吸収係数の高い $\mathrm{Fe}_{2} \mathrm{O}_{3}, \mathrm{CaO}, \mathrm{MnO}$ で, 土の主成分である $\mathrm{SiO}_{2}, \mathrm{Al}_{2} \mathrm{O}_{3}$ は直接影響するものと考えなくてよい。 $\mathrm{CaO}, \mathrm{MnO} の$ 含有率は少なく、注は定しているので,これらは実 際には吸収係数にかならずしも大きな影響を与えてい ない。これに対し， $\mathrm{Fe}_{2} \mathrm{O}_{3}$ は土により含有率が異なり， その影響するとこうは大きい。土による吸収係数の差 は注とんど $\mathrm{Fe}_{2} \mathrm{O}_{3}$ の含有率によるといってよい。この ほかたとえば黒ボクのように多くの有機物分を含む 土で市，有機物も吸収係数に大きな影響を与え無視す ることはできない。したがって，低ェネルギー $\gamma$ 線の 透過による浮遊土砂量の測定には, 測定すべき土砂が どのような化学組成のものであるかを調べ, 実際に計 数比 $\left(I_{2} / I_{1}\right)$ と土砂濃度 $(P)$ との関係を実測して, 更正 曲線を作成しなければならないことがわかる。

さて，本実験条件のもとでは， $\pm 500 \mathrm{mg} / l$ の精度で の浮遊土砂量の測定が可能であることを示したが，さ らに測定条件を改善した場合, 実際問題として, どの 程度まで精度を向上させることができるか, 本実験結 果をもとに考察してみる。いま, 土砂濃度 $P \mathrm{mg} / l$ の ときの透過後の $\gamma$ 線の計数を $I$ とし, 濃度ぶ $P+\Delta P$ $\mathrm{mg} / l$ に増加したとき計数が $(I-\Delta I)$ に減少したとする と,(3)式よりつぎの関係が成り立つ。

$$
\frac{I-\Delta I}{I}=\exp \left[-\Delta P \times 10^{-6}\left(\mu_{2}-\frac{\rho_{1}}{\rho_{2}} \mu_{1}\right) x\right]
$$

しかるに，Iが $(I-\Delta I)$ と区別されるためにはつぎの 関倸式を満足しなければならない。

$$
\begin{aligned}
& I-(I-\Delta I)>\sqrt{I+(I-\Delta I)} \\
\therefore \quad & \frac{I-\Delta I}{I}<1-\sqrt{\frac{2}{I}}
\end{aligned}
$$

\begin{tabular}{|c|c|c|c|c|c|c|c|c|c|c|c|}
\hline Component & $\begin{array}{l}\text { Ig. } \\
\text { loss }\end{array}$ & $\mathrm{SiO}_{2}$ & $\mathrm{Fe}_{2} \mathrm{O}_{3}$ & $\mathrm{Al}_{2} \mathrm{O}_{3}$ & $\mathrm{CaO}$ & $\mathrm{MgO}$ & $\mathrm{MnO}$ & Sulfide & $\mathrm{Na}_{2} \mathrm{O}$ & $\mathrm{K}_{2} \mathrm{O}$ & $\mu_{2}$ \\
\hline $\begin{array}{l}\text { Mass ab. coef. } \\
\text { Types of soil }\end{array}$ & 0.203 & 0.245 & 0.882 & 0.231 & 0.509 & 0.222 & 0.956 & & 0.214 & 0.483 & \\
\hline Miwa & 5.50 & 5.513 & 8.45 & 2.010 & 0.05 & 7.67 & 0.19 & 0.035 & - & - & 0.296 \\
\hline Tama loam & 11.24 & 42.00 & 13.85 & 29.45 & 0.02 & 0.73 & 0.25 & 0.004 & - & - & 0.325 \\
\hline Musashi loam & 11.86 & 43.86 & 13.80 & 27.65 & 0.02 & 0.93 & 0.23 & 0.011 & 一 & - & 0.325 \\
\hline Kuroboku & 31.53 & 27.85 & 12.46 & 22.40 & 0.02 & 3.77 & 0.18 & 0.007 & - & - & 0.303 \\
\hline Kanumatsuchi & 14.69 & 38.59 & 5.15 & 37.80 & 0.12 & 1.35 & 0.25 & 0.005 & - & - & 0.271 \\
\hline Bentonite & 5.83 & 73.01 & 1.45 & 13.92 & 0.03 & 2.81 & 0.04 & 0.018 & 1.82 & 0.33 & 0.240 \\
\hline
\end{tabular}

Table 2 Chemical components of the soils 
(4)および(5)式から， $\Delta P$ なる濃度変化が計数の変化と して, 明らかに認められるためには，次式を満足しな ければならない。

$$
\Delta P>\frac{-2.303}{10^{-6} \cdot x \cdot\left(\mu_{2}-\frac{\rho_{1}}{\rho_{2}} \mu_{1}\right)} \cdot \log \left(1-\sqrt{\frac{2}{I}}\right)
$$

すなわち，測定精度をあげるためには(6)式の右辺をで きるだけ小さくすればよいことになる。

したがって，測定精度を向上させるためには，つぎ の 2 通りの方法が考えられる。

i ）計数值 $I$ を大きくし, 計数值の統計的変動を相対 的に小さくする。

ii ） $\gamma$ 線の土砂溶液中の透過距離 $x$ を大きくする。

i ）の方法において，計数值を大きくするためには， 計数率を大きくし，計測時間を長くとればよい。しか し，実際には検出器にもおのずとその性能に限界があ り，無制限に計数率を大きくすることはできない。現 実に利用可能な実験装置の性能としては，せいぜい 6 $\times 10^{5} \mathrm{cpm}$ 程度であろ 万。一方, 計測時間も非常に長 くとることは実際的でなく，せいぜい10 min が限度で あろう。したがって，i）の点から本実験結果以上に 精度を向上させることは，さして期待できない。ii ） に関しては，結局， $\gamma$ 線源の量を増せばよいことにな
る。価格，取扱い上の問題点を考慮しても，まず $1 \mathrm{Ci}$ は使用できよ5。このとき，i ）の条件を満足した5

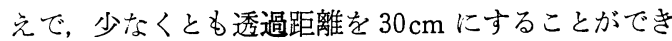
る。したがって，これによる精度向上は十分可能で， 測定精度は本実験結果の $1 / 3$ 以下，すなわち， $150 \mathrm{mg} / l$ 程度にすることが期待できる。

\section{4. むすび}

${ }^{241} \mathrm{Am} 960 \mathrm{keV}, \quad \gamma$ 線を利用して， $\gamma$ 線透過法によ る浮遊土砂量の測定法を室内実験により検討した。こ の結果, 土砂濃度にして, $\pm 500 \mathrm{mg} / l$ の精度での測定 ができることを示し，また，実験条件をさらに改善し た場合 $\pm 150 \mathrm{mg} / l$ 程度の精度での測定が期待できるこ とを示した。

$\gamma$ 線の透過による浮遊土砂量の測定は, 測定精度の 点では従来法にまだまだ少り，一般河川の浮遊土砂量 の測定にはかならずしも満足できるものではないが, とくに浮遊土砂量が問題となる諸河川では，目的を十 分果せる測定精度といってよい。

\section{文献}

1）石原藤次郎, 他：土砂含有度測定器の試作, 建設 省技術研究報告, p.33（1956） 